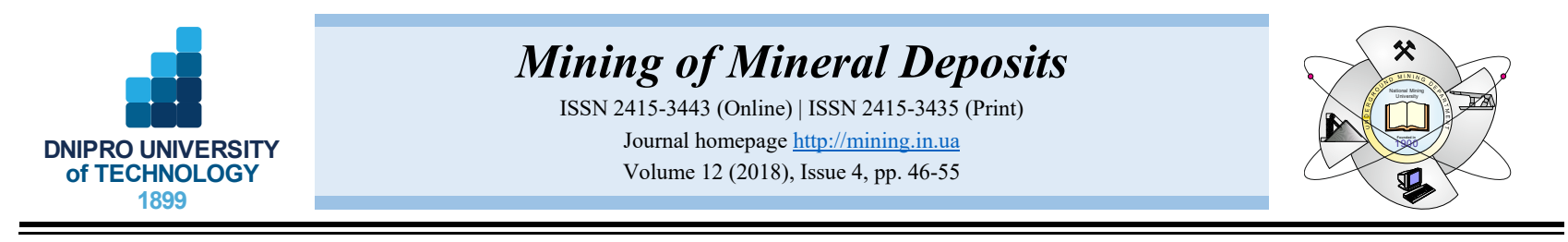

UDC 622.833.52:622.284.76

https://doi.org/10.15407/mining12.04.046

\title{
ANALYSIS OF THE EFFICIENCY OF GEOMECHANICAL MODEL OF MINE WORKING BASED ON COMPUTATIONAL AND FIELD STUDIES
}

\author{
V. Fomychov ${ }^{1}$, O. Mamaikin ${ }^{1,2 *}$, Yu. Demchenko ${ }^{1,3}$, O. Prykhorchuk ${ }^{4}$, J. Jarosz ${ }^{5}$ \\ ${ }^{1}$ Dnipro University of Technology, Dnipro, Ukraine \\ ${ }^{2}$ Dnipro Research Institute of Forensic Examination, Dnipro, Ukraine \\ ${ }^{3}$ Science Research Institute of Mining Problems of Academy of Engineering Sciences of Ukraine, Dnipro, Ukraine \\ ${ }^{4}$ MM "Pershotravneve", PJSC "DTEK Pavlohradvuhillia”, Mykolaivka, Ukraine \\ ${ }^{5}$ Mineral and Energy Economy Research Institute of the Polish Academy of Sciences, Krakow, Poland \\ *Corresponding author: e-mail mamaykin@yahoo.com, tel.+380508104769
}

\begin{abstract}
Purpose is to substantiate the efficiency of geomechanical model of the mine working on the basis of qualitative and quantitative parameters of stress and strain state of the mine working and to compare the results of computational experiment both with the results obtained while designing mine working support and with the results of field studies under mine conditions.
\end{abstract}

Methods. The studies consisted of three stages. Stage one involved development of the computational model and, using a finite-element method (ANSYS Software Package), and performance of computational experiment for mining and geological conditions of MM "Pokrovske". Stage two involved field measurements in the mine working with the support pattern developed according to the results of first stage of the research. Characteristic points were selected to determined separate stress and deformation components of a geomechanical system. Stage three dealt with comparative analysis of both computational and field experiments to define the efficiency of the selected computational model and the engineering solutions.

Findings. The substantiated physical and mathematical model as well as geometry of computational region of the geomechanical system have made is possible to determine to a high precision stress and strain state of all the components of mine working support and neighbouring rock mass. Analysis of changes in mine working border, while calculating and full-scale measuring, has demonstrated high accuracy degree in description of deformation processes within the rock mass. Qualitative changes in stresses within the selected anchors, in the process of the stope plane movement, correspond in their appearance to the curves of graphs obtained as a result of calculations.

Originality. For the first time, complex multicriteria approach has been proposed and applied to determine efficiency of the selected support scheme based on the measurements of mine working border displacement and internal effects of the support components; the approach makes it possible to evaluate adequacy of the selected computational scheme while predicting changes in the geomechanical system state.

Practical implications. The developed innovative methodology to prove the efficiency of selecting optimal system for mine working support helps reduce design costs and cut production expenses while mounting and operating the support from a holistic perspective. Validation of the fact that calculated results of stress and strain state of a geomechanical system correspond to the data of field measurements in terms of various stress and deformation criteria provides the possibility of the computational model interpolation with respect to the mine workings driven and designed under similar mining and geological conditions.

Keywords: rock mass, mineworking, stress and strain state, field experiments, anchors, mine working borders

\section{INTRODUCTION}

Studies of stability of reused mine workings driven in terms of different mining and engineering conditions are always closely connected with idealization of both enclosing rock mass and structural support components
(Van der Merwe \& Madden, 2010; Salli \& Mamajkin, 2012). That compulsory measure results in incompliance between calculated and real indices of stress and strain state of a geomechanical system. As a result, accuracy of the calculations as well as the efficiency of engineering

C 2018. V. Fomychov, O. Mamaikin, Yu. Demchenko, O. Prykhorchuk, J. Jarosz. Published by the Dnipro University of Technology on behalf of Mining of Mineral Deposits. This is an Open Access article distributed under the terms of the Creative Commons Attribution License (http://creativecommons.org/licenses/by/4.0/),

which permits unrestricted reuse, distribution, and reproduction in any medium, provided the original work is properly cited. 
solutions made on their basis may fail to provide the invariance of operational characteristics for a mine working (Piwniak, Bondarenko, Salli, Pavlenko, \& Dychkovskiy, 2007; Sdvizhkova, Babets, \& Smirnov, 2014). The problem is aggravated by a wide range of mechanical characteristics of rocks and technological schemes of mine working supports applied while its designing. Thus, the issue on organizations and methodology to carry out comparative analysis of both experimental results and the ones obtained while operating a real mine working is not simplistic - it may have several variants of solution (Pivnyak \& Shashenko, 2015; Lozynskyi, Saik, Petlovanyi, Sai, \& Malanchuk, 2018).

Search for optimal indices of geomechanical system has the form of multiparametric task which solution region should be reduced. To do that, one should determine adequacy criteria of the obtained experimental data (Fomychov, Kovalevska, \& Vivcharenko, 2011; Fomychov, 2012). Such criteria should describe the results of both computational experiment and field observations to the fullest extent possible. They should make it possible to interpret the considered data unambiguously while performing comparative analysis of stress and strain state of a geomechanical system (Shevchuk, Ivanik, Lavrenyuk, \& Saveliev, 2017). The selected characteristics should be mutually independent describing various aspects of stress and strain distribution within certain elements of a geomechanical object under consideration (Lazarević, Uroš, \& Čengija, 2017).

The selected analytic model of a computational experiment developed while designing a mine working, may be actualized by means of complex studies of a geomechanical system under field conditions. In this context, the obtained data are tested for the degree and types of deviations between calculation results and field measurements.
When optimality of the solution being taken is confirmed, then it is possible to formulate the database to analyze further projects to develop supports for a mine working operated under similar conditions. Such studies emphasize a separate task to determine connecting regularities of the criteria for various characteristics of changes in stress and strain state of a geomechanical system.

\section{RESEARCH METHODOLOGY AND STATEMENT OF THE PROBLEM}

Three measuring stations were set while driving $5^{\text {th }}$ southern belt entry of block 10 to confirm the results of computational experiment aimed at searching for the most expedient scheme to support reused mine workings operated under mining and geological conditions of Pokrovske colliery group. All the activities to measure maximum stresses within the roof anchors beginning from the support mounting up to the mine working abandoning were performed within each measuring stations. Stations one and three are located at the distance of $100 \mathrm{~m}$ from the starting and terminal points of a belt entry; station two is located in the middle of that distance (Fig. 1).

Plane of anchors setting does not coincide with the plane of frame work location. Thus, deformation characteristics of both mine working border and the frame itself were measured at the distance of $0.4 \mathrm{~m}$ from the anchor setting plane being taken further as a basic plane during the process of graph construction and analysis. Those peculiarities of field experiment performance have not effected the quality of the studies as analytic region of the computational experiment does not take into consideration those features of mine working support.

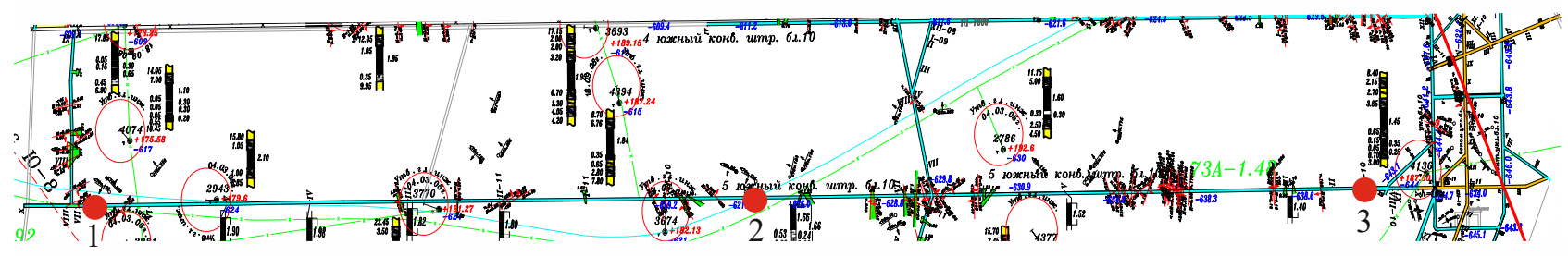

Figure 1. Fragment of a work layout in terms of extraction site of block 10 of Krasnoarmiiska-Zahidna No. 1 mine

Total vertical displacements of the mine working border were determined by means of a laser ranger with digital control systems (Sztubecki, Bujarkiewicz, \& Mrowczynska, 2017). Measurements performed along vertical axis of the mine working make it possible to define rock convergence within the roof and floor. That helps compare the obtained results of both computational and field experiments according to the majority of techniques to evaluate operational mine working state (Bondarenko, Symanovych, \& Koval, 2012; Mamaykin, 2015).

Measurements in terms of all three stations have resulted in the dependences having common character as for all the considered objects and their characteristics. Maximum linear indices of deviations from average values are within the range of $2-6 \%$. Consequently, the obtained measuring results are analyzed in terms of ave- raged indices. Taking into consideration the model to carry out computational experiment involving calculations which describe discretely the changes in mine working geometry, measurements were performed with considerable time interval. Measurements were performed in three ways: measurement of anchors involved analogous tension sensors connected to external bus of a computer; vertical displacements of mine working floor and roof were measured by a laser ranger with digital control systems; and changes in mine working border were measured by means of special techniques which results require further additional processing.

The technique is based on a mathematical model of mine working border development in terms of the totality of the selected points recorded under field conditions with further analysis of the obtained pattern involving 
database of laboratory and field experimental results (Fomychov, Kovalevska, \& Vivcharenko, 2011). It means the implementation of differentiation approach for evaluation of a mine working while its operation applying the analysis of mine working border changes as a closed geometrical area being limited by the totality of interconnected geometrical objects.

The considered system of mine working border control consists of two main parts: part one includes physical elements of the system located immediately within the mine workings, they comprise photofixation stations, support anchors, and set of replaceable reflectors; part two includes software being integrated or used in parallel with information system of mine control.

Stage one of the preparation for the use of the considered system involves setting of support anchors of $0.45 \mathrm{~m}$ long within the selected cross-sections of the mine working. It is desirable to set those anchors after a drifting face as early as possible. Support anchors are used to mounter place able reflectors. The reflectors determine the areas to locate control points for photofixation of a specific mine working cross-section. Setting of support anchors is followed by taking a reference image (with the help of a photofixation station); immediately after its fixing, separate table of states is opened in the system database for that image. Now, all the changes in mine working border will be considered basing upon the movements being further fixed in images.

From the viewpoint of the system to control mine working border, it is represented as a time-dependent totality of points connected geometrically within a space. The states are fixed with the help of relativistic database providing reference of those control points to a specific coordinates of the selected mine working. Thus, the system is capable of maintaining all the mine workings of a certain mine without any limitations in terms of computation power and software performance.

Generation of mathematical description of the mine working border is the basic stage of implementing system of control for mine working border. That stage involves mathematical tool of spline interpolation making it possible to use the supporting points, which coordinates are determined during the previous stage, to develop the mine working border; in this context, crosssection of the mine working preset by the support pattern is applied as the initial approximation.

Quality of that description effects considerably general operating efficiency of the mine working control system. Being adequately structured, data processing makes it possible to trace not only any changes in mine working border but also its spatial movements relative to the rock mass (Bartashchuk, 2017; Bezruchko, Diachenko, \& Urazka, 2018).

Database of mine working cross-section states is a key one for the considered system. It accumulates all the data describing mathematical model of the mine working border formed within the previous stage. The database is the link between the stages of processing and preparation of computational models and a system to analyze changes in the mine working border states.

Our method means cross analysis as the development of four-dimension (spatial coordinate system + time) mathematical model of a mine working along with multiparametric comparison of the model with the data obtained earlier for other mine workings operated under similar mining and geological conditions. The objective of the analysis is to identify critical deviations in the behaviour of the neighbouring rock mass demonstrated in the displacement growth pattern in terms of the mine working border. The analysis allows indicating peculiarities of support-rock mass interaction; thus, it helps select the most efficient engineering solutions to increase stability of a specific mine working.

\section{SUBSTANTIATING CRITERIA TO EVALUATE THE OBTAINED RESULTS}

While analyzing various calculation schemes applied by the authors in their computational experiments, it is clear that special attention is paid to the conditions of setting and further operation of anchoring for the reused mine working. In this context, studies were carried out to determine efficiency of a separate anchor setting - effect of geometrical place of an anchor hole and its setting angle. The available anchor load in various modes of its operations determined the degree of its setting efficiency (Bondarenko, Kovalevs'ka, \& Fomychov, 2012). On the other hand, availability of other support components, such as frame or protective strip, may complicate considerably the pattern of stress distribution both in the anchor and in its enclosing rock mass (Salli, Mamaykin, \& Smolanov). That is the reason why further field experiment involved studies of stress changes in terms of separate anchors; those states were the most characteristic ones in terms of the types of internal effort distribution according to the calculation results.

Changes in cross-section shape has become another comparative index describing state of the reused mine working both inside and outside the effect of stoping operations. As it is known, structure of the border load distribution is possible to be demonstrated in terms of deformation analysis of the proper border of the considered mine working. Though it is not always possible to identify to the full extent the laws of internal energy redistribution of support materials and rock layers, it is quite possible to analyze the admissible accuracy of the obtained calculated results (Bulat, Alekseiev, \& Baisarov, 2004; Latyshev, Matveev, Martushov, \& Eremizin, 2011). Moreover, these are the changes of mine working border which indicate the operation modes of an adjustable frame support.

Thus, while analyzing support border state, we not only obtain changes in the pattern of internal effects of the rock mass, but we also may predict behaviour of the frames mounted within a mine working. In that way, analysis of changes in the shape and range of the open mine working border is the one to be most informative from the viewpoint of a pattern containing stress stain state coincidences of a "rock mass - mine working support - protective structure" system. However, it should be taken into consideration that in certain cases the characteristic may be of rather conventional character due to the available natural outcroppings along the mine working border and its change under the effect of stoping operations. 
Time changes in the reused mine working height before and after stoping face drivage has become a third factor to be used while analyzing the adequacy of the performed computational experiments. Selection of that index is based first of all on its widespread use in other scientific papers related to the common topic under consideration - solution of problems to provide mine working stability. However, in terms of the considered engineering solutions and performed computational experiments, comparative analysis of the obtained results will be of different qualitative degree (Pariseau, 2011; Mamaykin, 2015). In case of successive calculations not taking into account time factor, the comparison will be performed with piecewise linear function which boundary values are determined as final results of a separate calculation carried out in terms of the computational experiment.

\section{MINING-GEOLOGICAL AND MINING- TECHNICAL CONDITIONS OF THE CONSIDERED WORKING AREA}

Working area of southern longwalls 5 of block No. 10 of $\mathrm{d}_{4}$ seam (MM "Pokrovske") has been selected to perform computational experiment by a finite-element method and carry out field studies concerning mine working stability; $5^{\text {th }}$ southern belt entry is the mine working under consideration. The working area is located within the left side of the block No. 10 panel; extraction pillar length is $2200 \mathrm{~m}$; longwall length is $290 \mathrm{~m}$; calculated commercial reserves are $1.7 \mathrm{mln} \mathrm{t}$. Extraction method is pillar-andpanel one with retreat mining along the seam strike towards capital inclined workings. Table 1 represents characteristics of the enclosing rocks where $5^{\text {th }}$ belt entry is driven. Depth of belt entry is $815 \mathrm{~m}$. Geological thickness of $\mathrm{d}_{4}$ seam within the working site is from 1.4 to $2.4 \mathrm{~m}$; average geological thickness within the extraction pillar is $2.1 \mathrm{~m}$; coal density is $1.35 \mathrm{t} / \mathrm{m}^{3}$.

Table 1. Characteristics of enclosing rocks of the seam within the considered area

\begin{tabular}{|c|c|}
\hline Parameters & $\begin{array}{c}\text { Value (characteristic) of } \\
\text { the parameters }\end{array}$ \\
\hline Coal grade & Coke coal \\
\hline \multicolumn{2}{|l|}{ Rocks } \\
\hline- main roof & Sandstone \\
\hline - immediate roof & Aleurolite \\
\hline - immediate floor & Aleurolite \\
\hline - main floor & Sandstone \\
\hline \multicolumn{2}{|l|}{ Rock categories } \\
\hline- main roof & $\mathrm{A}_{2}$ (medium cavability) \\
\hline - immediate roof & $\begin{array}{c}\mathrm{B}_{3} \text { (low stable) } \\
\mathrm{B}_{4} \text { (medium stable) }\end{array}$ \\
\hline- floor & $\mathrm{P}_{2-3}$ (medium stability) \\
\hline \multicolumn{2}{|l|}{ Protodiakonov scale of hardness } \\
\hline- main roof & $8.05-12.26$ \\
\hline - immediate roof & $4.0-6.5$ \\
\hline - immediate floor & $2.79-5.18$ \\
\hline- floor & $6.60-9.85$ \\
\hline \multicolumn{2}{|l|}{$\begin{array}{l}\text { Thickness of the enclosing } \\
\text { rocks, } m\end{array}$} \\
\hline- main roof & $0.00-5.00$ \\
\hline - immediate roof & $0.00-6.00$ \\
\hline - immediate floor & $0.00-4.00$ \\
\hline - floor & $6.00-15.00$ \\
\hline
\end{tabular}

Sulfur content of the seam is $0.5-0.6 \%$; ash content of the seam is $14-28 \%$; coal humidity is $2.0-3.5 \%$. Seam angle is 3 degrees. Natural gas-bearing capacity of the seam within the working area is from 15 to $25 \mathrm{~m}^{3} / \mathrm{t}$, water influx throughout the extraction pillar is $15-25 \mathrm{~m}^{3} / \mathrm{h}$. Stoping advance is $100 \mathrm{~m}$, if load is not more than $3000 \mathrm{t} /$ day in terms of gas factor. (Law et al., 1998; Bondarenko \& Dychkovskiy, 2006; Petlovanyi, Lozynskyi, Saik, \& Sai, 2018). Belt entry is reused and supported by a cast strip; double-row organ timbering is set. Support is of frame-andanchor type. Spacing of tent-shaped setting is $0.8 \mathrm{~m}$. Spacing of roof bolting is $0.8 \mathrm{~m}$. Tent-shaped support is of KShPU 17.7 type with roof-bolt setting.

The paper substantiates the efficiency of geomechanical model of a belt entry under the mentioned mining and geological conditions by comparing results of computational experiment obtained while mine working support designing and field studies under mine conditions.

\section{RESULTS}

\subsection{Analysis of roof-bolting state of development workings inside and outside the zone of stoping operations effect}

Stress state of anchors set within the roof and walls of the mine working according to the support pattern was measured within three stations in a time discrete way according to the position of a stope plane relative to cross-section of the mine working where anchors were set. Figures 2-4 demonstrate the results of comparing the calculated and averaged measuring values of maximum reduced stresses $\sigma$ within the selected anchors.

First, consider changes in the state of central anchors represented by graphs in Figure 2. As it is seen, qualitative and quantitative indices of the represented graphs coincide to a considerable extent. Absolute deviation between calculated and field values is not more than $13 \%$ being $7 \%$ on average.

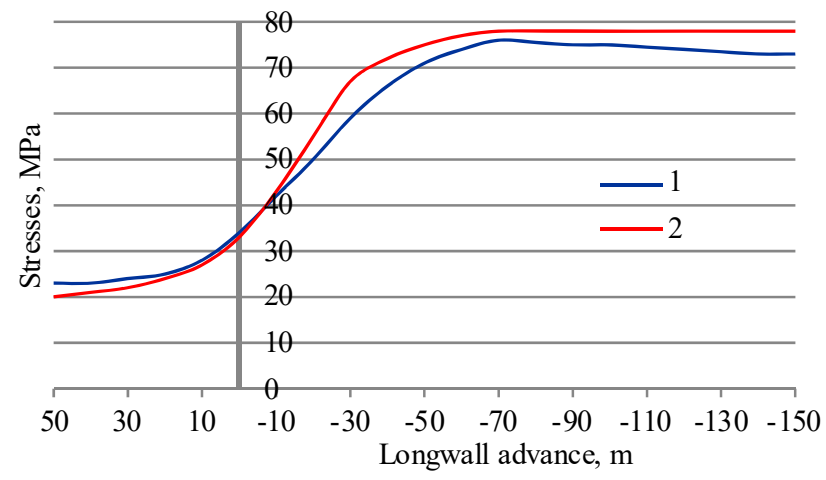

Figure 2. Changes in stress state of the central anchor set within the mine working roof: 1 and 2 -field and calculated values respectively

Apart from the approximating curve, Figure 2 demonstrates accurate values of field measurements performed in terms of three measuring stations. Further, we will not show the points to simplify consideration of the graphs.

Measurements were performed in each cross-section in terms of five anchors being set as follows: an anchor at the upper point of the mine working roof (central); the third anchors in succession from the central one (they are 
set within the mine working roof); and two outermost elongated anchors set in mine working walls. Selection of the anchors is determined by the pattern of distribution of their stresses in the calculation process.

In terms of outermost elongated anchors (Fig. 3), both calculations and field observations have demonstrated the fact that the pattern of changes in the maximums of reduced stresses $\sigma$ turns out to be perfectly-matched. Quantitative deviations for both anchors are not more than $7 \%$ being commeasurable to the average computation error in complex physical and mathematical models.

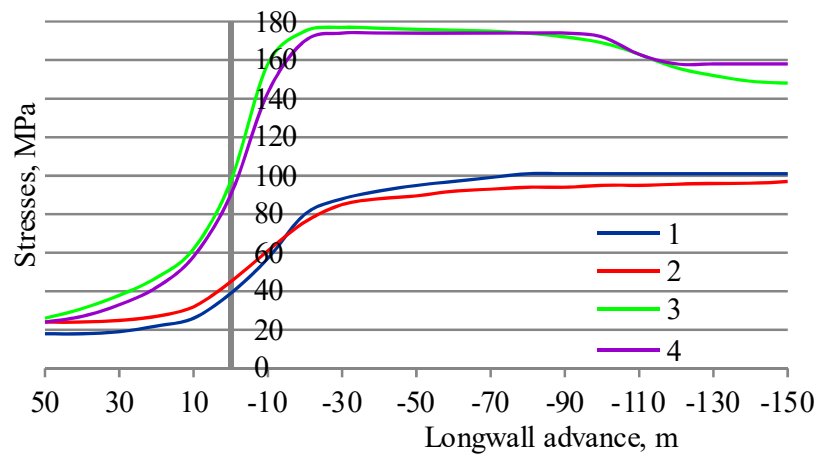

Figure 3. Changes in stress state of the anchors while longwall advancing for outermost elongated anchors towards the unmined rock mass: 1 and 2 -field and calculated values respectively, and for outermost elongated anchors set towards the stoping; 3 and 4 -field and calculated values respectively

Such indices of calculated and field values convergence may only indicate high adequacy degree of the developed computational model relative to the real mining and technical characteristics of the enclosing rock mass and its interaction with the components of support and protection systems. In this context, one should take into consideration the fact that these are the anchors which state is described by graphs in Figure 3 that are at the most complex situation from the viewpoint of external loading.

Figure 4 compares the obtained values of field and calculated experiments for the anchors set in the roof and on each side of the central anchor.

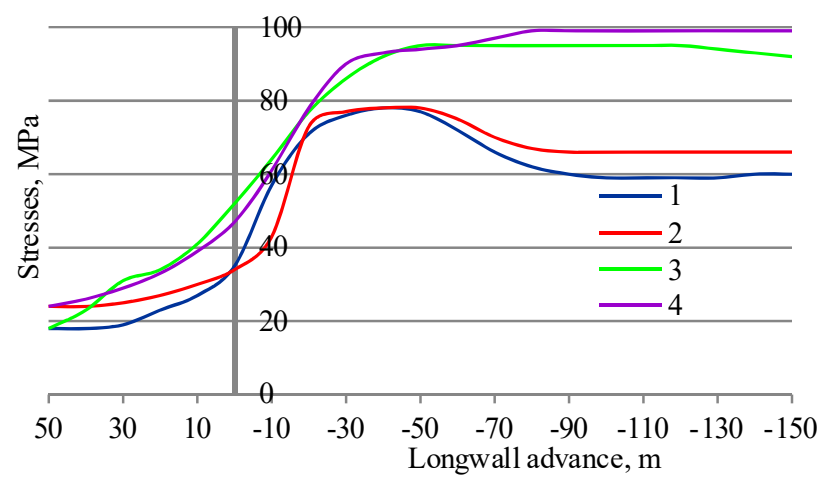

Figure 4. Changes in stress state of the anchors while longwall advancing for the anchor being third from the central one towards the unmined rock mass: 1 and 2 -field and calculated values respectively, and for the anchor being third from the central one towards the stoping; 3 and 4 -field and calculated values respectively
It is clearly seen that in both cases nature of the changes in maximums of $\sigma$ stresses coincides qualitatively. Deviations of absolute values for the anchor set towards the unmined rock mass is mot more than $12 \%$; in terms of the anchor from the stoping side, maximum deviations are not more than $30 \%$.

General character of the graphs in Figures 3 and 4 corresponds to a three-phase model of anchor operation in terms of reused mine workings. However, in terms of quality, anchors of the unmined wall and the ones of stoping-transition area operate differently; nevertheless, that corresponds to the obtained field observations.

The defined deviations in absolute values of the considered graphs correspond to two zones: zone of stope passing the plane of measuring stations and maximum distance of the face from that plane. In case one, the error is caused by the available considerable gradient of stress growth within the considered system; that always results in flattening of absolute values while performing numerical computation. In case two, one may clearly observe the effect of time changes in strength characteristics of the rock mass that is sure to be taken into account in terms of the obtained computational model.

In general, the obtained calculated results mostly exceed the values obtained while measuring; that demonstrates the acceptable quality of strength characteristics of rock bolting which configuration has been obtained as a result of computational experiment based upon multiparametric recursive nonlinear model.

\subsection{Analysis of changes in the mine working border under field conditions and while performing calculations taking into account nonlinear characteristics of the rock mass}

Six support anchors were set in each of three crosssections (their locations correspond to the anchor measuring stations) while studying changes in mine working border; setting depth was $0.6 \mathrm{~m}$ that was stipulated by considerable loosening degree of neighbouring rock mass. Those anchors were arranged as follows: two of them were set in the mine working floor at similar distances from the axis of its vertical symmetry; two more were set symmetrically to each other lower than $0.1 \mathrm{~m}$ of the lower boundary of pliability node of KShPU support; and two more were also set symmetrically but higher than the pliability node by $0.8 \mathrm{~m}$.

Measurements were performed along the whole interval of mine working operation to determine possible qualitative rapid changes due to sudden roof or walls caving. Since no disturbances of that kind were recorded, four most characteristic state represented in Figure 5 were selected for comparative analysis of the mine working border. Table 2 (Fig. 5a) and Table 3 (Fig. 5b) demonstrate measurement data used to obtain the diagrams.

The obtained borders both while calculating and as a result of field measurements have a set of quantitative deviations expressed as follows: first, changes in the mine working border during calculations is of more symmetric character than the ones being the result of measurements when mine working wall, exposed to the stoping, is deformed more intensely than the opposite one; second, longitudinal border changes in Figure $5 \mathrm{~b}$ are uniform both in floor and roof while, in terms of field conditions, roof 
rock convergence is 1.5 times more; and third, as a result of calculations, deformation rate of the mine working (Fig. 5b) is practically constant, but mea-surements indicate its growth with time (Fig. 5a). As a result, linear deviations of the obtained borders, calculated and measured, are up to $0.24 \mathrm{~m}$ at the points of greatest deviations and $0.11 \mathrm{~m}$ on average within all the splines.

(a)

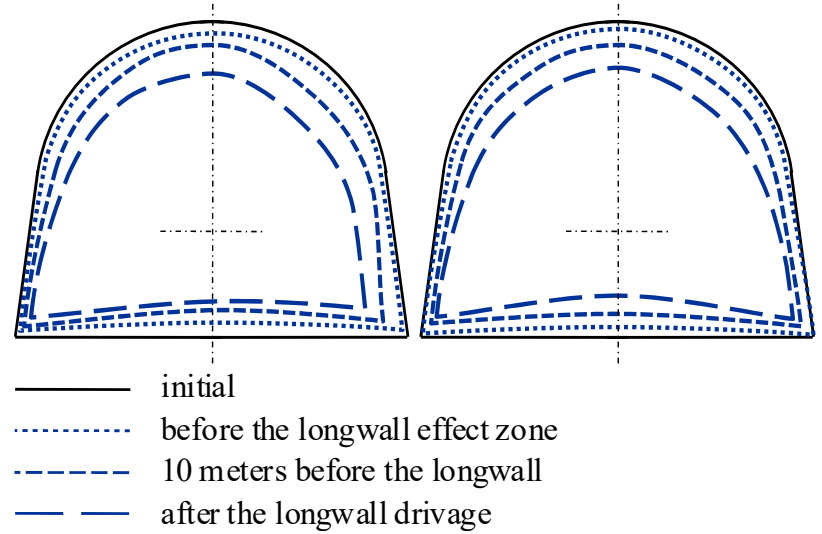

Figure 5. Changes in there used mine working border obtained: (a) as a result of field studies; (b) as a result of performed calculations

Table 2. Deformation of the mine working border in terms of mine conditions

\begin{tabular}{|c|c|c|c|c|c|c|}
\hline \multirow{3}{*}{$\begin{array}{c}\text { Control } \\
\text { point }\end{array}$} & \multicolumn{6}{|c|}{$\begin{array}{l}\text { Displacements, recorded under field conditions, } \\
\mathrm{mm}\end{array}$} \\
\hline & \multicolumn{2}{|c|}{$\begin{array}{c}\text { before the zone } \\
\text { of longwall } \\
\text { effect }\end{array}$} & \multicolumn{2}{|c|}{$\begin{array}{l}10 \mathrm{~m} \text { before } \\
\text { the longwall }\end{array}$} & \multicolumn{2}{|c|}{$\begin{array}{c}\text { after the } \\
\text { longwall } \\
\text { drivage }\end{array}$} \\
\hline & $\mathrm{X}$ & $\mathrm{Y}$ & $\mathrm{X}$ & $\mathrm{Y}$ & $X$ & $\mathrm{Y}$ \\
\hline 1 & 19 & 49 & 136 & 174 & 273 & 314 \\
\hline 2 & -21 & 34 & -289 & 216 & -468 & 388 \\
\hline 3 & 28 & 33 & 71 & 82 & 102 & 117 \\
\hline 4 & -25 & 37 & -269 & 117 & -453 & 245 \\
\hline 5 & -6 & -31 & 45 & -122 & 86 & -187 \\
\hline 6 & -11 & -42 & -202 & -194 & -420 & -324 \\
\hline
\end{tabular}

Table 3. Deformation of the mine working border obtained in terms of calculations

Displacements, recorded under field conditions, $\mathrm{mm}$

\begin{tabular}{ccccccc}
\multirow{2}{*}{$\begin{array}{c}\text { Control } \\
\text { point }\end{array}$} & $\begin{array}{c}\text { before the zone } \\
\text { of longwall } \\
\text { effect }\end{array}$ & \multicolumn{2}{c}{$\begin{array}{c}\text { 10 m before } \\
\text { the longwall }\end{array}$} & \multicolumn{2}{c}{$\begin{array}{c}\text { after the } \\
\text { longwall } \\
\text { drivage }\end{array}$} \\
\cline { 2 - 7 } & $\mathrm{X}$ & $\mathrm{Y}$ & $\mathrm{X}$ & $\mathrm{Y}$ & $\mathrm{X}$ & $\mathrm{Y}$ \\
\hline 1 & 18 & 20 & 124 & 142 & 269 & 298 \\
2 & -17 & 22 & -172 & 166 & -386 & 347 \\
3 & 18 & 17 & 56 & 61 & 104 & 102 \\
4 & -12 & 14 & -125 & 98 & -289 & 204 \\
5 & 8 & -18 & 120 & -129 & 198 & -292 \\
6 & -7 & -18 & -112 & -137 & -187 & -297 \\
\hline
\end{tabular}

However, contrary to qualitative indices of mine working border changes, quantitative ones expressed by residual area of cross-section inside, have demonstrated much higher degree of mutual correspondence being not more than $16 \%$ for all the pairs under analysis. Thus, the performed analysis makes it possible to draw conclusions on the correspondence of physical nature of deformation distributions along the mine working border between calculated values and the ones obtained owing to field observations; that helps predict the behaviour of pliable supports in the context of the task being solved on the basis of multiparametric nonlinear recursive model.

\subsection{Determining efficiency of the applied measures to protect reused mine working while longwall is driven along it}

Evaluate the development of vertical convergence of mine working roof and floor rocks when calculations and measurements are performed at each of three measuring stations (Fig. 1). The studies have demonstrated considerable qualitative deviations of the performed measurements in terms of all three stations while the difference in quantitative indices is not more than the range of $80 \mathrm{~mm}$. Thus, it turns out to be impossible to consider averaged characteristics of measurements in terms of all field cross-sections.

Results of field observations obtained at first measuring station (Fig. 6) have the largest difference of $89 \mathrm{~mm}$ within the distance between -25 and $-50 \mathrm{~m}$. In this context, when longwall displaces from the measuring stations, values of vertical displacements approach the calculated ones becoming less than calculated values by $150 \mathrm{~m}$. In general, increase in vertical displacements of the reused mine working appears to be higher than the calculated ones at the initial moment of passing through ORP zone with further rapid decrease along with the growing distance to it.

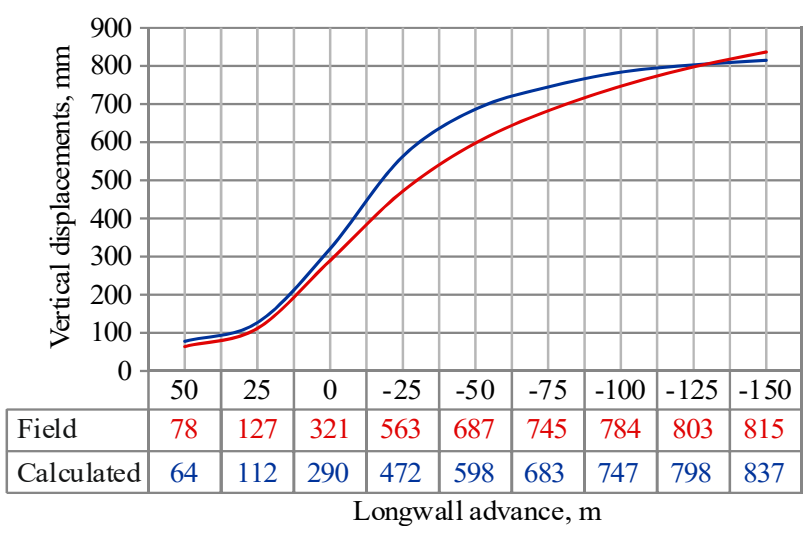

Figure 6. Vertical displacements of roof and floor rocks of the reused mine working within the first measuring station

It means that in terms of first measuring station, it is possible to state that the computational model, having provided solid field-data correspondence indices on average, does not fully consider the structure of interaction of support and rock mass components; however, when the descriptions of protective structure are introduced into the calculation, that peculiarity of the computational model is leveled. In general, the performed analysis of comparing the obtained results for the first measuring station makes it possible to indicate satisfactory state of the performed computational analysis.

In terms of second measuring station (Fig. 7), field research data correspond to the obtained calculation results to a greater degree. Maximum difference between 
calculated and field data is $89 \mathrm{~mm}$ but within the distance of $-50 \ldots-75 \mathrm{~m}$. Here the measured deformations exceed the calculated ones though they change in a smoother way comparing to calculated ones; that determines higher correspondence degree of the obtained dependences.

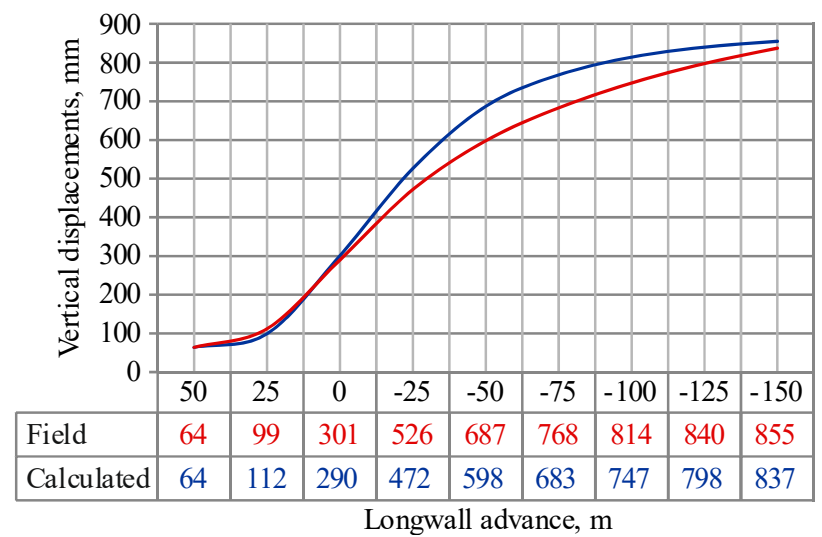

Figure 7. Vertical displacements of roof and floor rocks of the reused mine working within the second measuring station

If we compare the data represented in Figures 6-8, then it is possible to conclude on the fact that displacement patter obtained for second measuring station does not contain the effects of stopings driven perpendicularly to the longwall movement direction, i.e. assembling disassembling entry.

Studies within the third measuring station differ from the previous ones most of all (Fig. 8). Despite the fact that qualitatively represented graphs correspond better to the ones in Figure 6, there are serious differences in quantitative indices. In terms of distance -20 to $-50 \mathrm{~m}$, difference in calculated and field data is more than $100 \mathrm{~mm}$; at -25 point, the difference reaches $129 \mathrm{~mm}$. As a result, maximum deviation of the considered values for that measuring station are more than $23 \%$ being the worst index among all the pairs being compared.

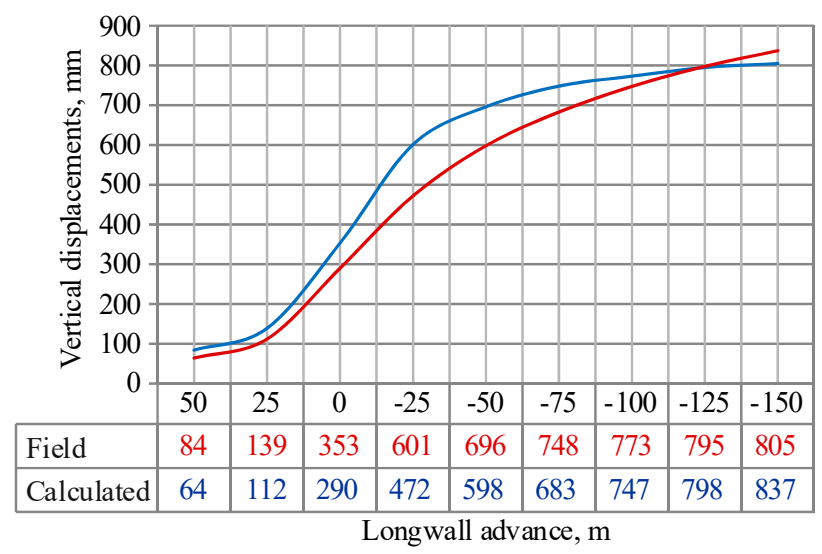

Figure 8. Vertical displacements of roof and floor rocks of the reused mine working within the third measuring station

In general, it should be noted that qualitative indices of changes in mine working height inside are similar for all the three stations. Up to the moment when longwall passes the cross-section plane, where there are compo- nents of a measuring station, and beginning from $100 \mathrm{~m}$ behind the longwall, calculated indices and measured values are close to each other; however, the range of -10 to $-100 \mathrm{~m}$ demonstrates considerable differences in the growth of vertical deformations of the reused mine working. Non-consideration of roof-lowering of the stope, resulting in its breakup, is the obvious fact influencing the quality of the obtained results. It is the lack of decrease in potential energy that does not allow implementing more intense growth of vertical stresses in a computational model.

Thus, changes in values of vertical displacements of mine working roof and floor while calculating in terms of qualitative indices do not correspond to the full extent the real conditions. However, in quantitative terms, the obtained maximum deviations are not more than $14 \%$ that allows speaking substantially about adequacy of the selected computational scheme obtained on the basis of multiparametric nonlinear recursive model.

\section{DISCUSSION}

Changes in stress and strain state of a geomechanical model of a mine working under field conditions demonstrate that the selected physical and mathematical model as well as the computational region geometry has made it possible to predict adequately the effect of mine working support upon the enclosing rock mass. Deformation growth of mine working border as well as its geometry changes recorded by means of the technique developed by the author (Bondarenko, Kovalevs'ka, \& Fomychov, 2012) has demonstrated that the loosened zones within the rock mass are formed according to the obtained calculation results.

Analysis of the results of mine working border measuring has shown that the selected technique describes rather adequately real deformation processes within the rock mass; at the same time, the technique makes it possible to have direct comparison of data arrays of computational and field experiments. The performed analysis has demonstrated: first - maximum quantitative deviations within the border deformations are observed within the mine working floor; second - while calculating, deformation pattern of the border relative to vertical axis of the mine working is displaced towards the stope, it is connected with the computational region modeling.

Components of the designed roof bolting within the considered geomechanical system perform the functions of internal forces redistribution according to the results of calculations obtained during computational experiment. Predicted changes in stress and strain state of a certain anchor, when stoping plane moves along the considered mine working, have coincided with the results of the field experiment measurements to a high precision. That indicates the right computational model being selected while designing the support for the mine working.

\section{CONCLUSIONS}

1. The selected criteria for evaluating the efficiency of a calculation model of a computational experiment are structurally independent. Deviations of field indices from the calculated ones are characterized by various types of dependences represented by timed nonlinear functions. 
2. Analysis of the considered computational model has demonstrated that description quality of a real geomechanical system corresponds least of all to the time interval of the stope plane passing through the plane where measurements are performed. Deviations in quantitative measurements are up to $160 \mathrm{~mm}$ in vertical displacements and up to $22 \%$ in terms of stress intensity at the selected points.

3 . The proposed methodology to carry out field experiments makes it possible to reveal the nature of changes in stress and strain states of a geomechanical system that, along with the computational experiment, helps obtain high-accuracy predictions, with deviation being within the limits of $7 \%$.

4. The obtained results have shown that the selected computational model has provided the implementation of the predicted changes in the state of geomechanical system of the mine working according to the selected support parameters. While analyzing, all the elements of the computational model have demonstrated high correlation degree between the calculated and field indices of the selected criteria.

\section{ACKNOWLEDGEMENTS}

The author wishes to thank the mine owner, Krasnoarmiiska-Zakhidna No. 1 (MM "Pokrovske"), engineers and technicians for assistance in experimental works and providing the necessary data.

\section{REFERENCES}

Bartashchuk, O.V. (2017). System organization of disjunctive tectonics in consolidated basement of Dnipro-Donets paleorift. Visnyk of V.N. Karazin Kharkiv National University Series Geology, Geography, Ecology, (47), 7-17. https://doi.org/10.26565/2410-7360-2017-47-01

Bezruchko, K.A., Diachenko, N., \& Urazka, M. (2018). Influence of the Western Donbass share dislocation zone on the formation of gas accumulations in coal-bearing sediments. Geodynamics, 1(24), 27-39.

https://doi.org/doi:10.23939/jgd2018.01.027

Bondarenko, V., \& Dychkovskiy, R. (2006). Methods of extraction of thin and rather thin coal seams in the works of the scientists of the Underground Mining Faculty (National Mining University). New Technological Solutions in Underground Mining, 21-25. https://doi.org/10.1201/noe0415401173.ch3

Bondarenko, V., Kovalevs'ka, I., \& Fomychov, V. (2012). Features of carrying out experiment using finite-element method at multivariate calculation of mine massif - combined support system. Geomechanical Processes During Underground Mining, 7-13.

https://doi.org/10.1201/b13157-3

Bondarenko, V., Symanovych, G., \& Koval, O. (2012). The mechanism of over-coal thin-layered massif deformation of weak rocks in a longwall. Geomechanical Processes During Underground Mining, 41-44. https://doi.org/10.1201/b13157-8

Bulat, A.F., Alekseiev, A.D., \& Baisarov, L.V. (2004). Improving the technique of stability retention of the reused mine workings in terms of longwall retreat mining. Donetsk: DUNVGO.

Fomychov, V., Kovalevska, I., \& Vivcharenko, O. (2011). Optimization of frame-bolt support in the development workings, using computer modeling method. In World Mining Congress, 267-278.
Fomychov, V. (2012). Premise development of clearing models of the frame - anchor support at nonlinear characteristics physics mediums behavior. Naukovyi Visnyk Natsionalnoho Hirnychoho Universytetu, (3), 45-52.

Latyshev, O., Matveev, A., Martushov, A., \& Eremizin, A. (2011). The forecast of strain characteristics jointing rock and massifs. Mining Journal News Establishment Higher Education, (7), 92-97.

Law, B.E., Ulmishek, G.F., Clayton, J.L., Kabyshev, B.P., Pashova, N.T., \& Krivosheya, V.A. (1998). Basin-centered gas evaluated in Dnieper-Donets basin, Donbas foldbelt, Ukraine. Oil and Gas Journal, 96(47), 74-78.

Lazarević, A.J., Uroš, M., \& Čengija, A. (2017). Fundamental models of structural stability. Rudarsko Geolosko Naftni Zbornik, 32(2), 37-46.

https://doi.org/10.17794/rgn.2017.2.5

Lozynskyi, V., Saik, P., Petlovanyi, M., Sai, K., \& Malanchuk, Y. (2018). Analytical research of the stress-deformed state in the rock massif around faulting. International Journal of Engineering Research in Africa, (35), 77-88. https://doi.org/10.4028/www.scientific.net/jera.35.77

Mamaykin, O. (2015). On the problem of operation schedule reliability improvement in mines. New Developments in Mining Engineering, 505-508. https://doi.org/10.1201/b19901-86

Pariseau, W.G. (2011). Design analysis in rock mechanics (second edition). London, United Kingdom: CRC Press, Taylor \& Francis Group. https://doi.org/doi:10.1201/b11461

Petlovanyi, M.V., Lozynskyi, V.H., Saik, P.B., \& Sai, K.S. (2018). Modern experience of low-coal seams underground mining in Ukraine. Article in press. International Journal of Mining Science and Technology. https://doi.org/10.1016/j.ijmst.2018.05.014

Pivnyak, G.G., \& Shashenko, O.M. (2015). Innovations and safety for coal mines in Ukraine. Naukovyi Visnyk Natsionalnoho Hirnychoho Universytetu, (6), 118-121.

Piwniak, G.G., Bondarenko, V.I., Salli, V.I., Pavlenko, I.I., \& Dychkovskiy, R.O. (2007). Limits to economic viability of extraction of thin coal seams in Ukraine. Technical, Technological and Economic Aspects of Thin-Seams Coal Mining International Mining Forum 2007, 129-132. https://doi.org/10.1201/noe0415436700.ch16

Salli, S., \& Mamajkin, O. (2012). Ecological aspects of the quantitative assessment of productive streams of coal mines. Geomechanical Processes During Underground Mining, 115-118. https://doi.org/10.1201/b13157-20

Salli, S., Mamaykin, O., \& Smolanov, S. (2013). Inner potential of technological networks of coal mines. Annual ScientificTechnical Colletion - Mining of Mineral Deposits, 243-246. https://doi.org/10.1201/b16354-46

Sdvizhkova, Ye.A., Babets, D.V., \& Smirnov, A.V. (2014). Support loading of assembly chamber in terms of Western Donbas plough longwall. Naukovyi Visnyk Natsionalnoho Hirnychoho Universytetu, (5). 26-32.

Shevchuk, V., Ivanik, O., Lavrenyuk, M., \& Saveliev, M. (2017). Development of algorithms and software components for modeling of stress-strain state of rocks during coal deposits exploration. Visnyk of Taras Shevchenko National University of Kyiv. Geology, 1(76), 85-92. https://doi.org/10.17721/1728-2713.76.12

Sztubecki, J., Bujarkiewicz, A., \& Mrowczynska, M. (2017). Vertical displacements analysis of measurements achieved by laser station. IOP Conference Series: Earth and Environmental Science, (95), 032003. https://doi.org/10.1088/1755-1315/95/3/032003

Van der Merwe, J.N., \& Madden, B.J. (2002). Rock engineering for underground coal mining. Johannesburg, South Africa: The Southern African Institute of Mining and Metallurgy. 


\section{АНАЛІЗ ЕФЕКТИВНОСТІ ГЕОМЕХАНІЧНОЇ МОДЕЛІ ВИЇМКОВОЇ ВИРОБКИ НА ОСНОВІ ОБЧИСЛЮВАЛЬНИХ НАТУРНИХ ДОСЛІДЖЕНЬ}

\section{В. Фомичов, О. Мамайкін, Ю. Демченко, О. Прихорчук, Я. Ярош}

Мета. Обгрунтування ефективності геомеханічної моделі виїмкової виробки на основі порівняння якісних і кількісних параметрів напружено-деформованого стану виїмкової виробки за результатами розрахунку обчислювального експерименту з отриманими на етапі проектування кріплення виробки й натурними дослідженнями в шахтних умовах.

Методика. Дослідження проводилися в три етапи. На першому етапі розроблялася розрахункова модель і за допомогою методу скінченних елементів (програмний пакет ANSYS) проводився обчислювальний експеримент для гірничо-геологічних умов шахтоуправління «Покровське». На другому етапі виконані натурні заміри у виробці зі схемою кріплення, визначеною за результатами першого етапу досліджень. Були обрані характерні точки, в яких визначалися окремі компоненти напружень або деформацій геомеханічної системи. Третій етап полягав у проведенні порівняльного аналізу даних обчислювального й натурного експерименту з метою визначення ефективності обраної розрахункової моделі й прийнятих технологічних рішень.

Результати. Обгрунтовані фізико-математична модель та геометрія розрахункової області геомеханічної системи дозволили 3 високою точністю визначити напружено-деформований стан усіх елементів кріплення виробки й приконтурного породного масиву. Аналіз зміни контуру виробки при розрахунках і натурних виміpax показав високий ступінь точності описання деформаційних процесів, що протікають у породному масиві. Якісні зміни напружень в обраних анкерах при русі площини очисного вибою відповідають за видом кривим графіків, отриманих у результаті розрахунків.

Наукова новизна. Вперше запропоновано та використано комплексний багатокритеріальний підхід для визначення ефективності обраної схеми кріплення, заснований на вимірах переміщень контуру виробки і внутрішніх зусиль елементів кріплення, що дозволяе оцінити адекватність обраної обчислювальної схеми при прогнозуванні зміни стану геомеханічної системи.

Практична значимість. Розроблена нова методика підтвердження ефективності вибору оптимальної системи підтримання виїмкової виробки дозволяє комплексно скоротити затрати на проведення проектних заходів та зменшити витрати виробництва при установці й експлуатації кріплення. Підтвердження відповідності результатів розрахунків напружено-деформованого стану геомеханічної системи і даних натурних замірів за різними критеріями напружень та деформацій забезпечує можливість інтерполяції обчислювальної моделі для пройдених виробок і виробок, що проектуються, у схожих гірничо-геологічних умовах.

Ключові слова: породний масив, виробка, напружено-деформований стан, натурний експеримент, анкера, контур виробки

\section{АНАЛИЗ ЭФФЕКТИВНОСТИ ГЕОМЕХАНИЧЕСКОЙ МОДЕЛИ ВЫЕМОЧНОЙ ВЫРАБОТКИ НА ОСНОВЕ ВЫЧИСЛИТЕЛЬНЫХ НАТУРНЫХ ИССЛЕДОВАНИЙ}

\section{В. Фомичев, А. Мамайкин, Ю. Демченко, А. Прихорчук, Я. Ярош}

Цель. Обоснование эффективности геомеханической модели выемочной выработки на основании сравнения качественных и количественных параметров напряженно-деформированного состояния выемочной выработки по результатам расчета вычислительного эксперимента с полученными на этапе проектирования крепи выработки и натурными исследованиями в шахтных условиях.

Методика. Исследования проводились в три этапа. На первом этапе разрабатывалась расчетная модель и при помощи метода конечных элементов (программный пакет ANSYS) проводился вычислительный эксперимент для горно-геологических условий шахтоуправления «Покровское». На втором этапе выполнены натурные замеры в выработке со схемой крепления, определенной по результатам первого этапа исследований. Были избраны характерные точки, в которых определялись отдельные компоненты напряжений или деформаций геомеханической системы. Третий этап заключался в проведении сравнительного анализа данных вычислительного и натурного эксперимента с целью определения эффективности выбранной расчетной модели и принятых технологических решений.

Результаты. Обоснованные физико-математическая модель и геометрия расчетной области геомеханической системы позволили с высокой точностью определить напряженно-деформированное состояние всех элементов крепи выработки и приконтурного породного массива. Анализ изменения контура выработки при расчетах и натурных замерах показал высокую степень точности описания деформационных процессов, протекающих в породном массиве. Качественные изменения напряжений в выбранных анкерах при движении плоскости очистного забоя соответствуют по виду кривым графиков, полученных в результате расчетов.

Научная новизна. Впервые предложен и использован комплексный многокритериальный подход для определения эффективности выбранной схемы крепления, основанный на замерах перемещений контура выработки и внутренних усилий элементов крепления, позволяющий оценить адекватность выбранной вычислительной схемы при прогнозировании изменения состояния геомеханической системы.

Практическая значимость. Разработанная новая методика подтверждения эффективности выбора оптимальной системы поддержания выемочной выработки позволяет комплексно сократить затраты на проведение проектных мероприятий и уменьшить издержки производства при установке и эксплуатации крепи. Подтвер- 
ждение соответствия результатов расчетов напряженно-деформированного состояния геомеханической системы и данных натурных замеров по различным критериям напряжений и деформаций обеспечивает возможность интерполяции вычислительной модели для пройденных и проектируемых выработок в схожих горногеологических условиях.

Ключевые слова: породный массив, выработка, напряженно-деформированное состояние, натурный эксперимент, анкера, контур выработки

\section{ARTICLE INFO}

Received: 16 February 2018

Accepted: 6 November 2018

Available online: 15 November 2018

\section{ABOUT AUTHORS}

Vadym Fomychov, Doctor of Technical Sciences, Associate Professor of the Underground Mining Department, Dnipro University of Technology, 19 Yavornytskoho Ave., 49005, Dnipro, Ukraine. E-mail: fomichov@,inbox.ru

Oleksandr Mamaikin, Candidate of Technical Sciences, Associate Professor of the Underground Mining Department, Dnipro University of Technology, 19 Yavornytskoho Ave., 49005, Dnipro, Ukraine. E-mail: mamaykin@yahoo.com

Yurii Demchenko, Candidate of Technical Sciences, Associate Professor of the Underground Mining Department, Dnipro University of Technology, 19 Yavornytskoho Ave., 49005, Dnipro, Ukraine. E-mail: dem.yu@nmu.org.ua

Oleksandr Prykhorchuk, Chief Engineer of the MM "Pershotravneve", PJSC "DTEK Pavlohradvuhillia", 1d Pershotravneva St, 52744, Mykolaivka, Ukraine.E-mail: PrikhorchukAI@dtek.com

Jacek Jarosz, Doctor of Philosophy, Deputy Head of the Division of Mineral Resource Acquisition, Mineral and Energy Economy Research Institute of the Polish Academy of Sciences, 7 Wybickiego St, Krakow, Poland. E-mail: jjarosz@,min-pan.krakow.pl 